\title{
Histological and fluorescent microscope studies for evaluation carbon accumulation in trachea and bronchi of birds in polluted area in Wasit province
}

\author{
H.K. Karadi and A.M. Al- badri \\ * Department of Biology, College of Science, Wasit University, Iraq*
}

(Received December 6, 2017; Accepted January 5, 2018)

\begin{abstract}
The aim of this study was to detect the accumulation of carbon and determination its appearance in different areas of groups of ducks. Using special dyes to detect deposits of carbon particles. Also, using AO/ EB stains to detect early and late (progress) apoptosis that occurred due to the precipitated of carbon in both areas (Al-ahdeb oil field and brick factories areas) but late apoptosis occurred in bronchi of brick factories area more than oil field area. The histological examination of trachea showed no any indicator of accumulation of carbon in three different areas, whereas in bronchi showed the presence of carbon in polluted areas (Al-ahdeb oil field and brick factories areas) in different amounts.
\end{abstract}

Keywords: Histological, Fluorescent microscope, Carbon, Trachea, Bronchi, Birds Available online at http://www.vetmedmosul.com

$$
\begin{aligned}
& \text { دراسة نسيجية وباستخدام المجهر المتالق لتقدير تراكم الكاريون في الرغامي والقصبة الهوائية }
\end{aligned}
$$

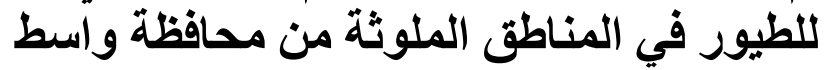

$$
\begin{aligned}
& \text { هايل خليل ابراهيم الكرادي و احمد مهدي صالج البدري } \\
& \text { قسم علوم الحياة، ، كلية العلوم، جامعة واسط، العر اق }
\end{aligned}
$$

الهدف من هذه الدر اسة هو الكثف عن تر اكم الكاربون وتحديد مظهره في مناطق مختلفة لمجمو عات من البط باستخدام اصباغ خاصة الكرية

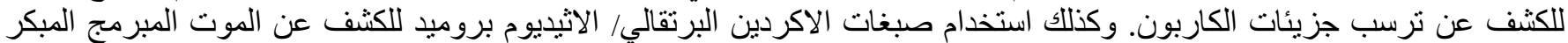

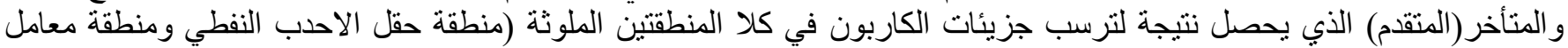

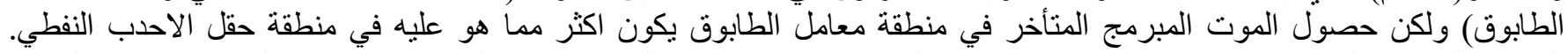

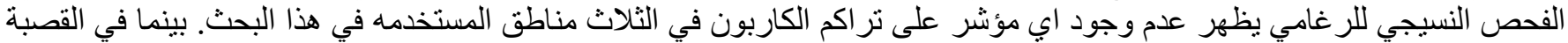
الهو ائية نلاحظ ترسب الكاربون في المناطق الملوثة (منطقة حقل الاحدب النفطي ومنطقة معامل الطابوق) وبكميات مختلقة.

\section{Introduction}

Birds differ from mammals because of particular structures in their respiratory system (1). The avian respiratory system consists of nasal cavity, larynx, trachea, syrinx, bronchi, lungs and multiple air sacs (2). Main functions of respiratory system in birds are exchange gases inflows and outflows, requirements of flight, voice output and temperature stability of bird body, air moved across breathing passage through the nasal cavity to the larynx then carry on by the trachea and go into syrinx in addition to bronchi (1).The trachea consiste of the tracheal cartilage rings (3). In birds, the number of rings in the trachea differs due to the length of the neck. The number of cartilage rings are usually $119-159$ in the trachea of birds (4). Trachea is a long tube runs alongside the esophagus. In birds is very 
similar to that of mammals, the trachea bifurcates into two main bronchi, the chief difference is that the hyaline cartilage rings are complete in birds (5). Histologically, it is lined with a columnar epithelium ciliated, containing numerous simple alveolar mucous glands. In the posterior portion of the trachea, the glands are exchanged by goblet cells. A lamina propria and submucosa are present, each consists of loose connective tissue and cartilage. The submucosa contains large amounts of elastic fibers (6).

The primary bronchi comprise of cartilaginous rings held together by connective tissue, they are extended from the trachea to the hilus of lungs (7). The dimensions of bronchus rings are diffrent in species of bird. The secondary bronchi originate from primary bronchi and have differ position with variable number, and named depending on the parts of the lung. They are dividing into Parabronchi (tertiary bronchi), and freely anastomosis with each other $(7,8)$. Bronchi appeared as short tubes stretch caudally from the syrinx to the hilus of the lung at the proximal third of the lung at the visceral surface. The bronchi laterally are against ascending, descending aorta and interior and inferior vena cava and partially at region attachment of hilus of lung covered with base of heart while ventral surface is opposite the esophagus and proximal part of the lung (9).

The mucosa of primary bronchi consisted of pseudostratified columnar epithelium ciliated with goblet cells. Lamina propria Loose C.T. presenting numerous lymphocytes (10). The muscular layer comprised of circularly or spirally oriented smooth muscle fibers. The Cartilaginous layer comprised of hyaline cartilage rings are present in the initial portions of the primary bronchi. They are replaced by plaques of cartilage within the intra pulmonary portion of the primary bronchi. The cartilaginous plaques are lost within the vestibulum (11). Carbon is unique among the elements in the large number and diversity of compounds it can form. With nitrogen, oxygen, hydrogen, and other elements, it forms a very numerous compounds, carbon atom often being connected to carbon atom. There are close to ten million known carbon compounds, many thousands of which are needed to organic and life processes (12). Black carbon (BC) is different from the elemental carbon (EC), which is generally observed with thermal optical methods. There are many provenance of $\mathrm{BC}$ such as combustion engines, coal and many materials. Consequently, $\mathrm{BC}$ is a global indicator of a variable mixture of PM from a large diversity of combustion sources and, when measured in the atmosphere, it is always linked with other substances from combustion sources, such as organic compounds (13). The black carbon particle is used as a generic term for any of the varies metrics (black sulfide, elemental carbon, black carbon or absorption coefficient) in general, but the study-specific terms are used when individual studies are described. The various optical measurements for $\mathrm{BCP}$ (BS, BC and Abs absorbance) are highly correlated $(14,15)$. However, the quantitative relation between thermally determined elemental carbon and optical measures of black carbon differences between cities, countries and types of position (for example, regional, urban, traffic), highlighting the need for site-specific standardization $(13,16)$. Anthracosis is caused by the accumulation of carbon, silica, and quartz particles and many materials in the macrophages, mucosa, and submucosa (17). Occupational exposures to these particles are causative factors for bronchial anthracosis (18). Although, in general, deposition of carbon particles, also iron, lead, cadmium and other inorganic or organic materials may consider sources of bronchi anthracosis (BA). It is usually discovered in patients with obstructive pulmonary disease, who do not complete the treatment and had radiological abnormalities (19). Long term exposure to carbon black dust causes damage to the respiratory system. The purpose of this study to know the relative proportion of carbon in oil field and brick factories areas and also know the apoptosis Which occurred as a result of the carbon accumulated.

\section{Materials anf methods}

\section{Animals and tissue preparation}

Eighteen mal for domestic ducks (Anas platyrhynchos) were collected from three different places in Wasit province. The birds are divided into three groups according to the area that collected from (Al-dejeli, Al-ahdab oil field and brick factories area) in Wasit. Each group contained six birds, all birds should be clinically healthy and devoid of any type of injuries. All domestic ducks were slaughtered, after that the trachea samples isolated from upper and lower part cervical region while the bronchi cut off from it. For histological study, several samples of the trachea and bronchi were fixed in formalin $10 \%$ for 72 hours and washed up in tap water for 2-3 hours, then samples were processed by routin histological techniques: dehydration, clearing, infiltration, embedding, cutting and staining with hematoxylin and eosin (H\&E) stain for appearing the general structure of the tissue, in addition with periodic acid Schiff stain (20) were used to detect deposits of carbon particles in paraffin sections.

\section{Fluorescent microscope method}

Acridin Orange (AO) / Ethidium bromide (EB) stains were used in this method to detect the apoptotic body. When this stain bound to DNA, the AO give the green color to cells, but the EB give the orange fluorescence. Acridine orange dye detects the live cells that suffered from the fragment (early apoptosis) whereas ethidium bromide detect the cells that lose its cytoplasmic membrane (dead cells). The blocks were sectioned $6 \mu \mathrm{m}$ thickness by 
microtome and then remove paraffin wax from sections by xylene (10-15) minutes. Sections were rehydrated in ethanol $(99 \%, 90 \%$, and $70 \%)$ then were passed to distilled water. Added acridine orange / ethidium bromide to slides for 10 minutes. Rinse slides with phosphate buffer saline to remove stain. Mounting with DPX mounting media (21).

\section{Results and discussion}

\section{Grossly study}

The dissections of three groups of duck showed that the trachea is a long tube runs alongside the esophagus. In birds is very similar to that of mammals. The trachea divides into two main bronchi (Fig. 1). These facts were compatible with (6) in domestic animals.

The macroscopic results in the first normal group (Aldejeli area) show the hale respiratory tract and didn't find any traces of contamination (Fig. 2).

In the second group (oil field area) and third group (in brick factories) found the carbon partices that spreed in the ducks body (Fig. 3).

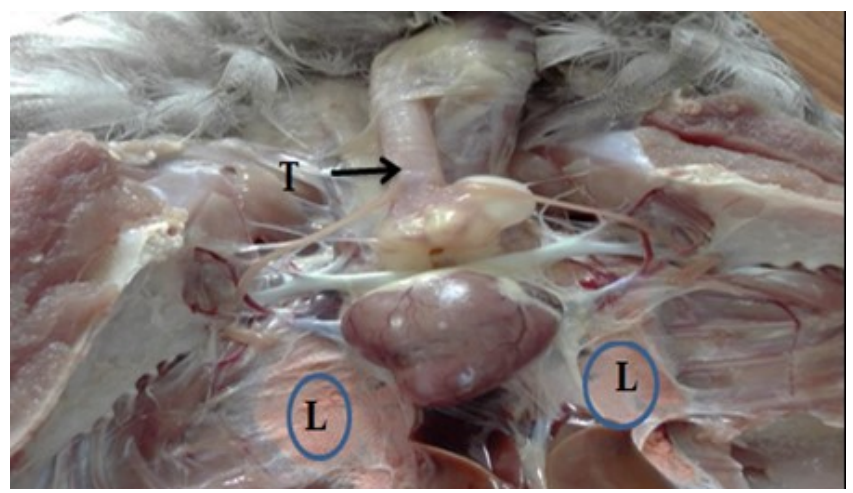

Figure 1: The duck body showing the location of trachea (T) and the lung (L).

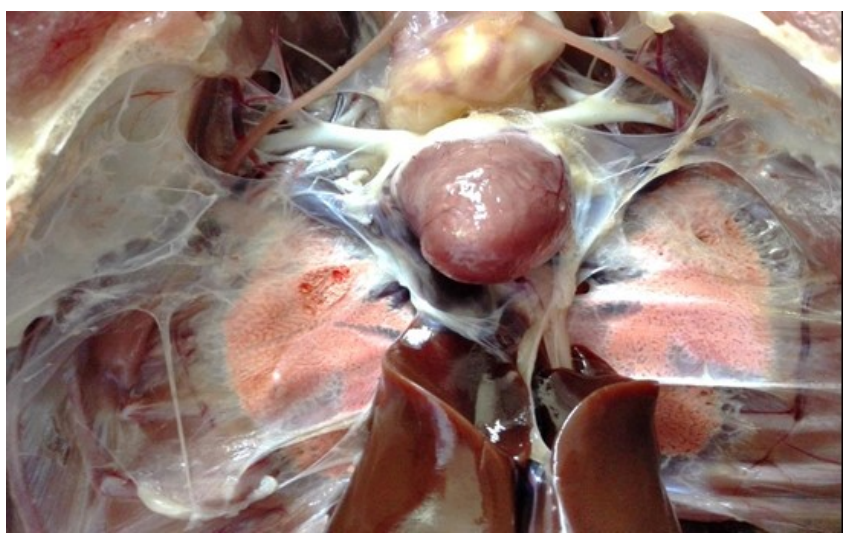

Figure 2: Gross appearance showing the clean ducks body in the first group (Al-dejeli area).

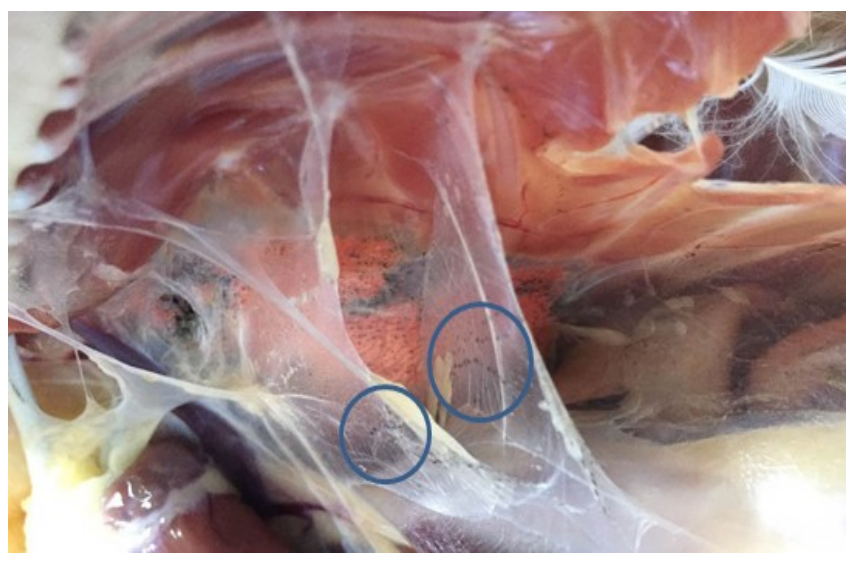

Figure 3: Gross appearance of air sac of bird showing the carbon particles in oil feild group.

This apparent results were similar to (22) they were studying the effect of anthracosis on many types of animals in Dhaka Zoo, the grossly observation found the presence of carbon particles as a large black spot to blackish discoloration in the lungs of many vertebrates.

\section{Histological results of trachea and bronchi Al-dejeli area (normal area)}

The mean of body weight of ducks (Anas platyrhynchos) was calculated. The mean of ducks in this area was about $1592 \pm 110.43$ (Table 1).

Table 1: Shows the mean body weight (gm.) in three groups of domestic ducks

\begin{tabular}{lc}
\hline Area of Ducks collection & Body Weight (Mean \pm SE) \\
\hline Al-dejeli area & $1592 \pm 110.43$ \\
Al-ahdab oil field area & $1459 \pm 141.83$ \\
Brick factories area & $1652 \pm 66.07$ \\
\hline
\end{tabular}

$\mathrm{SE}=$ standard error, $\mathrm{n}=6$ and $(\mathrm{P} \leq 0.05)$ between different areas.

The histological examination of cross section of trachea was reveald it was lined with pseudostratified columnar ciliated. The cilia arrangement resembles to wave to convey secretions (mucus) and entrapped particualets toward the nasopharynx. Also contain submucosa layer and hyaline cartilage tissue (Fig. 4).

These consequences was compatible with $(11,23-27)$ in goose, by $(9,28)$ in Japanese quail, $(29,30)$ in laying hens.

The histological examination of trachea with H\&E and Periodic acid- Schiff (PAS) stain showed only normal general histological structures with no indicator of carbon accumulation in trachea. Relatively the ratio of carbon accumulation (-) (Table 2). 
The mucosa of primary bronchi consisted of pseudostratified ciliated columnar epithelium with goblet cells. Lamina propria loose C.T. presenting numerous lymphocytes. The muscular layer consisted of circularly or spirally oriented smooth muscle fibers (Fig. 4). Histologically, this on comparable to $(9,26,31-35)$.

The histological and histochemical examination showed there was no indicator of carbon accumulation in primary bronchi and which appear in healthy or normal section $(5,6)$. Wherefore the percentage of carbon gathering in this part relatively was (-) (Table 2$)$.

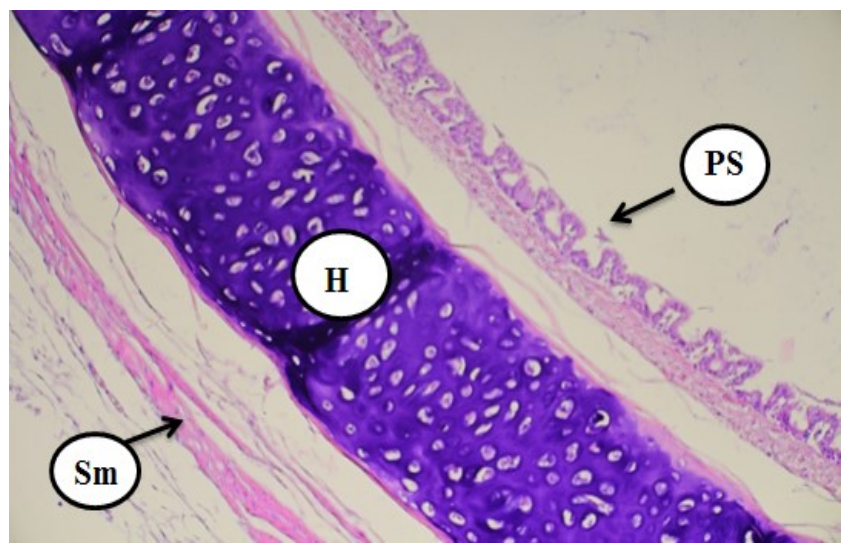

Figure 4: Microphtograph of bronchi in Duck (in normal area) showing that the bronchi was lined by ciliated pseudostratified columnar epithelium (PS), Hyaline cartilage $(\mathrm{H})$ and Smooth muscle (Sm )(H\&E stain, 200X).

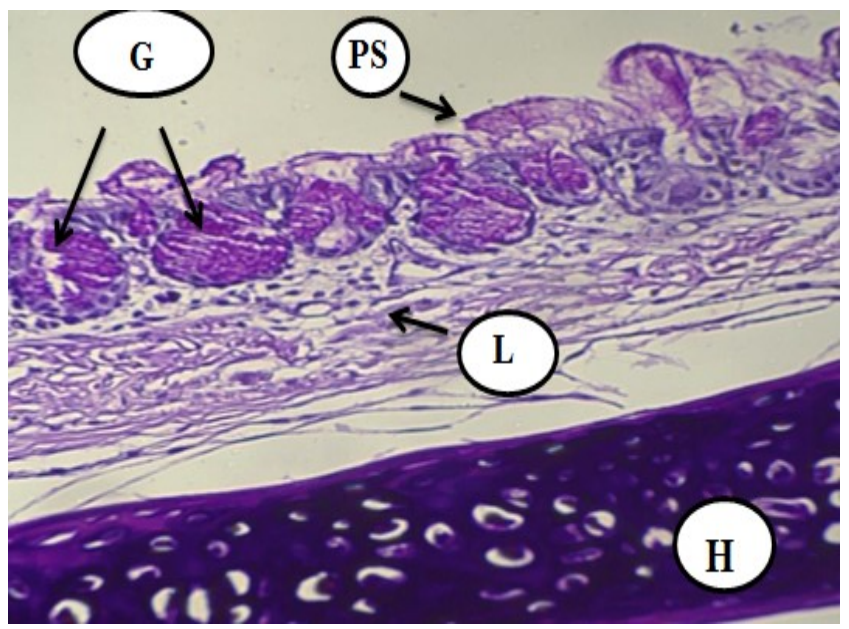

Figure 5: Microphtograph of bronchi in Duck (normal area) showing the ciliated pseudostratified columnar epithelium (PS), intraepithelial mucous glands (G), loose connective tissue of submucosa (L)and Hyaline cartilage $(\mathrm{H})$ without any accumulation of carbon (PAS stain, 400X).

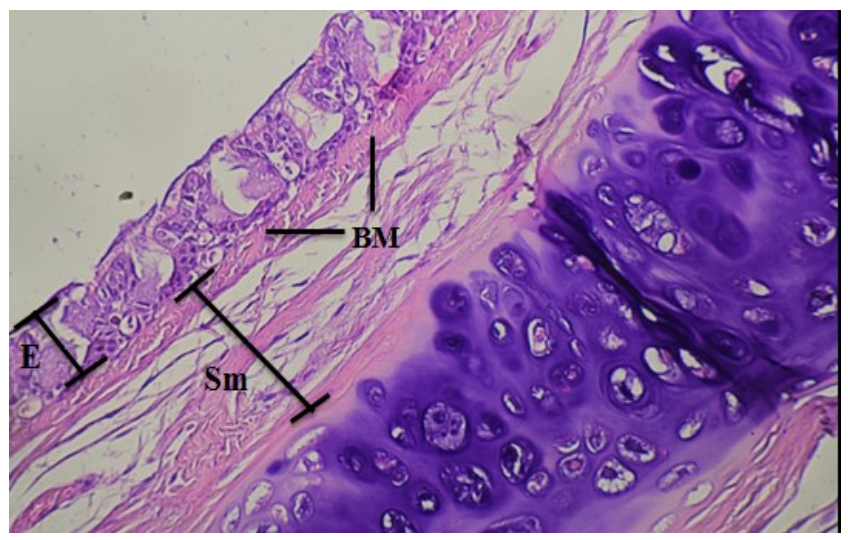

Figure 6: Microphtograph of bronchi in Duck (normal area) showing ciliated pseudostratified columnar epithelium (E), basement membrane (BM) and submucosa layer (Sm) without any appearance of carbon (H\&E stain, 400X).

\section{Trachea, Bronchia in brick factories and Oil fields area}

The histological results for trachea showed it was lined with ciliated pseudostratified columnar epithelium, the lamina propria was loose connective tissue comprised from collagen bundles and blood vessels (Fig. 7). This observation was similar with $(26,29,36)$. They described the histological structure of the trachea in domestic birds.

The histological examination with routine stain (H\&E) and PAS stain showed high amounts of goblet cells and congestion of the mucosa, that indicated that the birds suffer from unhealthy respiratory symptoms (Fig. 8,9). Therefore, there was no indicator of carbon accumulation in the trachea of birds which collected from brick factories area and oil fields area. Relatively, the proportion of carbon deposition of trachea in this groups was (-) (Table 2).

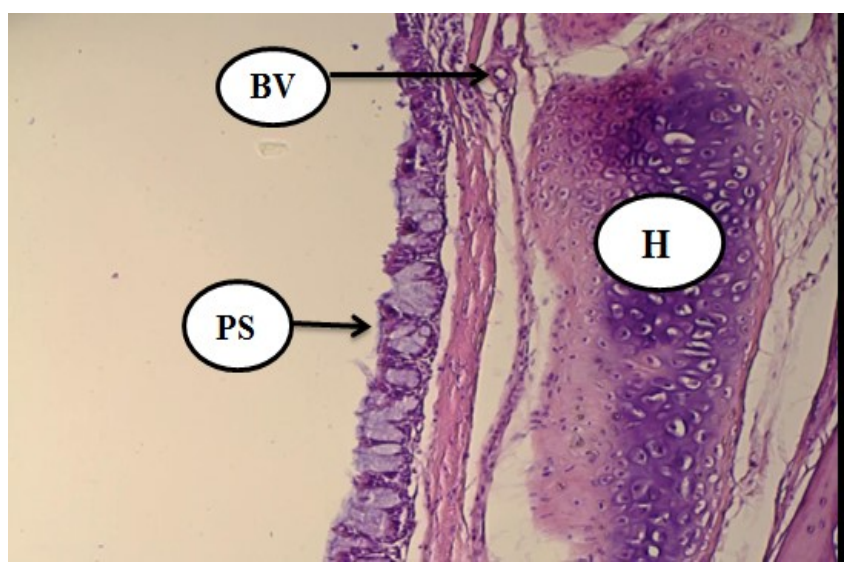

Figure 7: Microphtograph of trachea in Duck (in brick factories) showing the trachea was lined by ciliated pseudostratified columnar epithelium (PS), hyaline cartilage $(\mathrm{H})$ and Blood vessel (BV) (H\&E stain, 400X). 


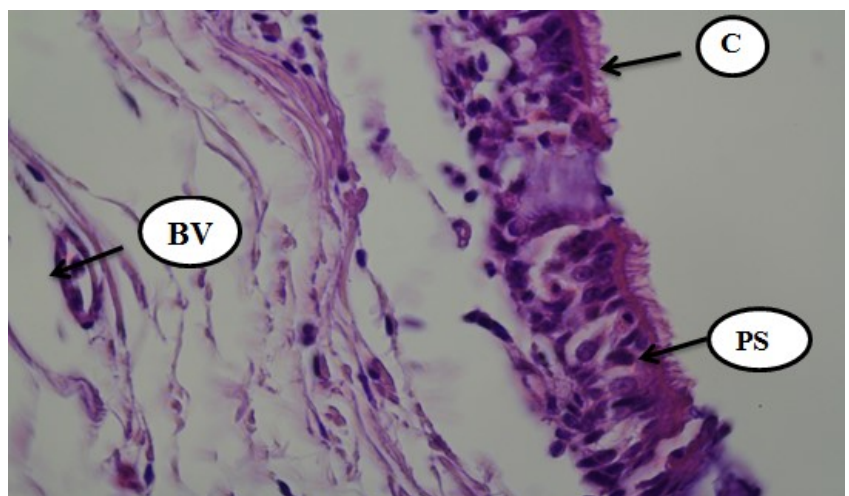

Figure 8: Microphtograph of trachea in Duck (in brick factories) showing the trachea was lined by Ciliated pseudostratified columnar epithelium (PS), The cilia (C) and Blood vessel (BV) without any appearance of carbon (H\&E stain, 1000X).

Table 2: Shows the relative proportion of carbon in trachea, bronchi and lung in three places examined birds (ducks)

\begin{tabular}{lcc}
\hline Area of ducks & Trachea & Bronchi \\
\hline Normal area & - & - \\
Oil field area & - & + \\
Brick factories area & - & ++ \\
\hline
\end{tabular}

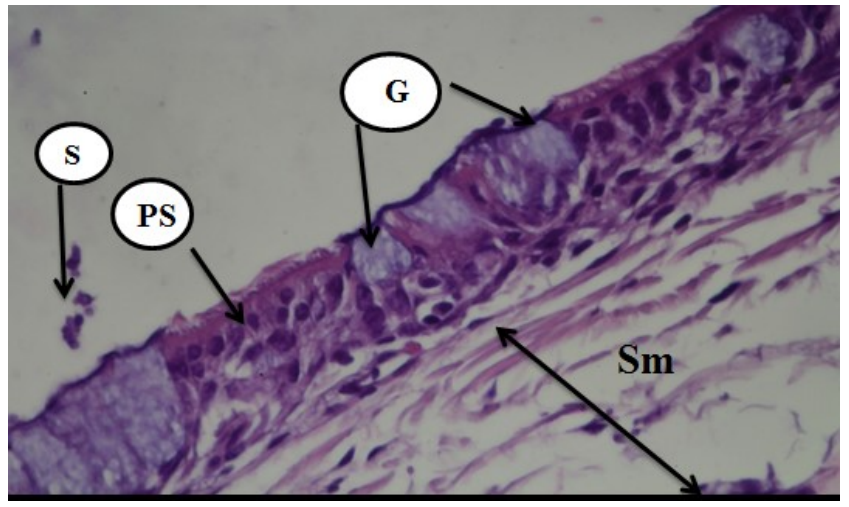

Figure 9: Microphtograph of trachea in Duck (in oil filed) showing the trachea was lined by Ciliated pseudostratified columnar epithelium (PS), goblet cells (G) and there was no any accumulation of carbon with secession parts of the mucosal layer (S) (H\&E stain, 1000X).

Likely, that because of the nature synthesis of the trachea of bird, which have well developed intraepithelial glands. Moreover, (29) mention that the secretion (mucigen) of goblet cells will released in the tracheal lumen and become mucin which sticky substance that simply hold on to inhaled foreign particles and lastly these particles were removed by cilia activity of columnar epithelial cells.
The basic structure of primary bronchi consisted of a series -C- shape of cartilage rings connect together by annular ligaments. The secondary bronchi originate from primary bronchi and have respiratory epithelium simple columnar with absent of goblet cells. The secondary bronchi opened within parabronchi of lung (Fig. 10). This structure mention by $(9,34,35)$.

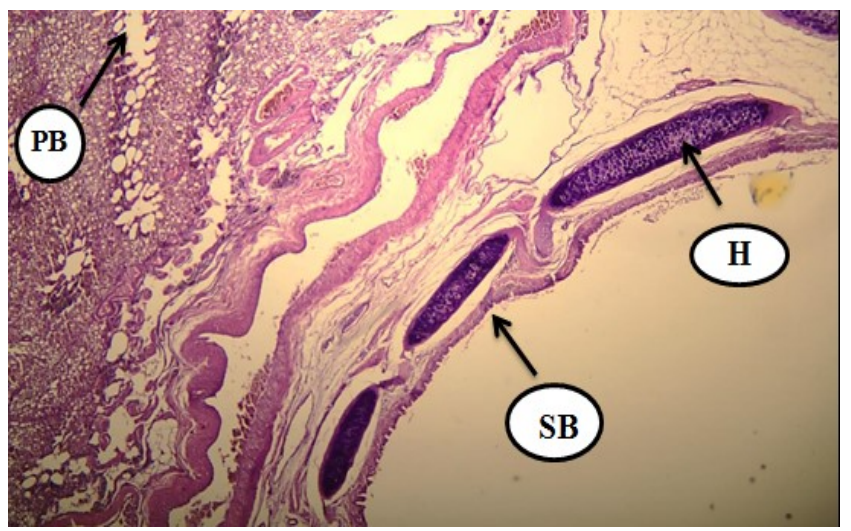

Figure 10: Microphtograph of lung in Duck (in brick factories ) showing the Secondary bronchi (SB), incomplete hyaline cartilage $(\mathrm{H})$ and parabronchi $(\mathrm{PB})(\mathrm{H} \& \mathrm{E}$ stain, 40X).

In brick factories area, the light microscopic results of the bronchi with routine stain (H\&E), in addition to PAS stain showed a great proportion of carbon particle accumulation in the mucosal layer (Fig. 11), relatively estimated was $(++)$ (Table 2). While their findings of the bronchi that were taken from the oil field area, appeared that the amount of precipitated carbon was less than the amount deposited in the brick area (Fig. 12) and assessment of its $(+)$ (Table 2).

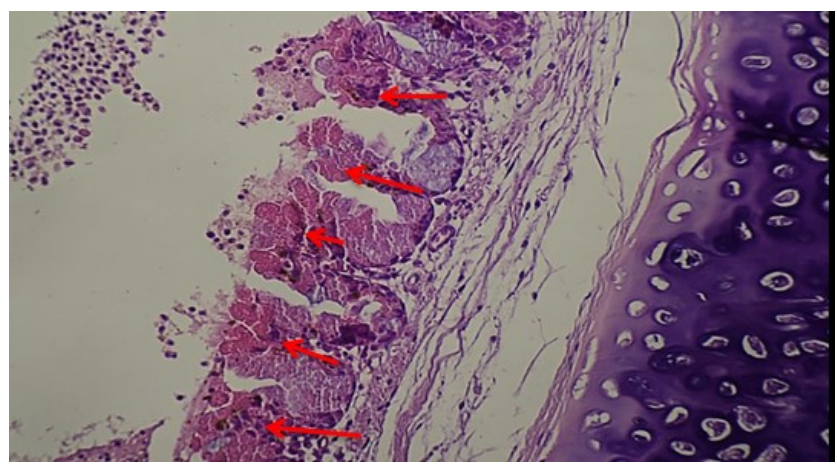

Figure 11: Microphtograph of bronchi in Duck (in brick factories area) showing the bronchi was lined by abnormal epithelia that contain secession parts in addition to accumulation of carbon in high amount (red arrows) (H\&E stain, 400X). 


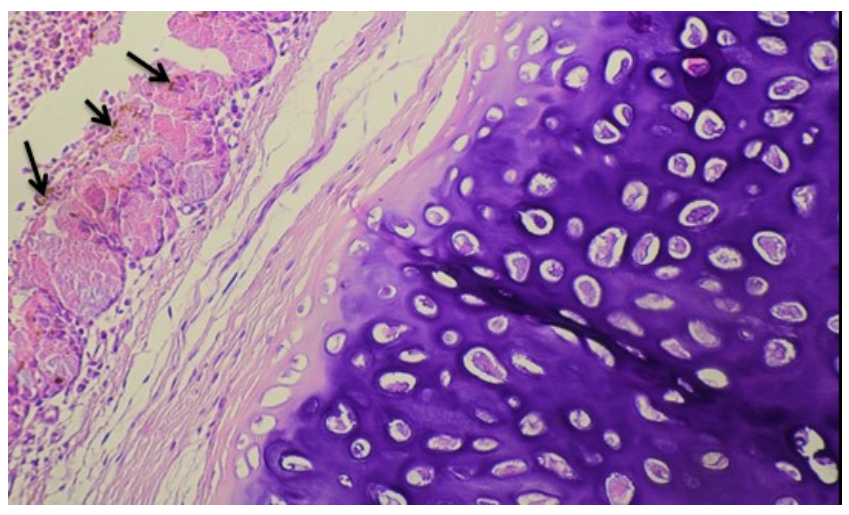

Figure 12: Microphtograph of bronchi in Duck (in oil field area) showing the bronchi was lined by abnormal epithelia that contain secession parts in addition to accumulation of carbon in little amount (arrows) (H\&E stain, 400X).

(37) they were observed dust particles in the mucosal layer of bronchi in rat and that lead to bronchial inflammation. The researcher (38) confirmed the high percentage of pollutants from the brick factories area and specifically $\mathrm{CO}, \mathrm{CO}_{2}$, dust particle and high density of smoke that emitted from the chimneys because of the use of crude oil as a fuel also primitive operating conditions, uncontrolled fuel burning system and incomplete burn of fuel. All these factors helped to increased pollution in the areas of brick factories. We believed through the results obtained, that the areas of the oil fields in less production of carbon and its compounds because and after the investigation we found that the Al-ahdab oil field contains filters that decreased the particulate matter emitted from it.

For detect the effect of carbon components on cellular structure of respiratory tract, the fluorescent microscope results by using acridine orange / ethidium bromide stains showed the late apoptosis was occurring in all epithelia cells of bronchi in the brick factories area (Fig. 13). On the other hand, the bronchi in oil field area was showing early apoptosis in the epithelium (Fig. 14) (Table 3).

(38) through their research about the techniques of fluorescent stains, they said that the live cells appeared as green nucleus, cells that suffered from condensed or fragmented chromatin (early apoptotic cells) appeared as bright green nucleus and late apoptotic cells display condensed and fragmented orange chromatin.

Table 3: Shows the early and late apoptosis in bronchi and lung in polluted area of examined birds (ducks)

\begin{tabular}{lcc}
\hline \multirow{2}{*}{ Area of ducks } & \multicolumn{2}{c}{ Bronchi } \\
\cline { 2 - 3 } & Early apoptotic & Late apoptotic \\
\hline Oil field area & ++ & + \\
Brick factories area & + & ++ \\
\hline
\end{tabular}

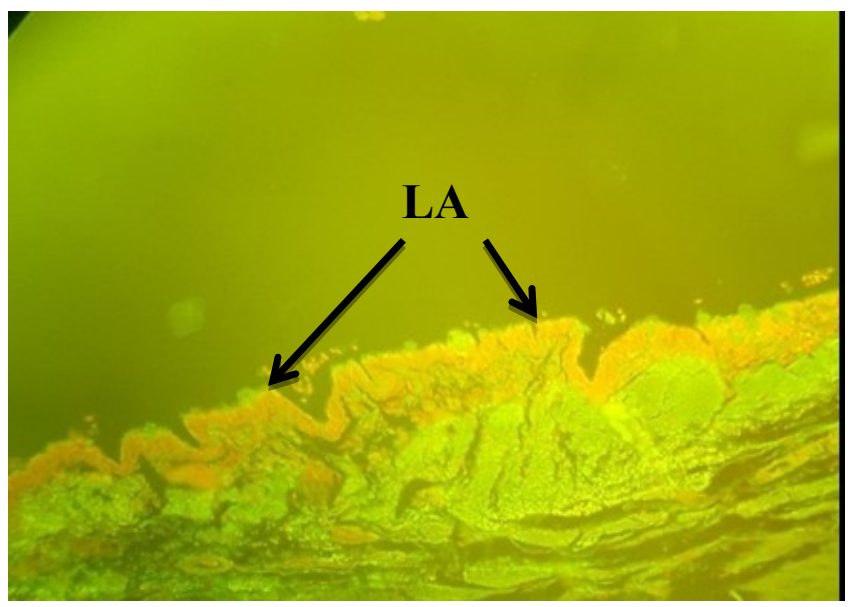

Figure 13: Microphtograph by fluorescent microscope analysis of bronchi in Duck (in brick factories) showing the late apoptosis (LA) was occurring in the epithelium. (AO/EB, stain, 1000X).

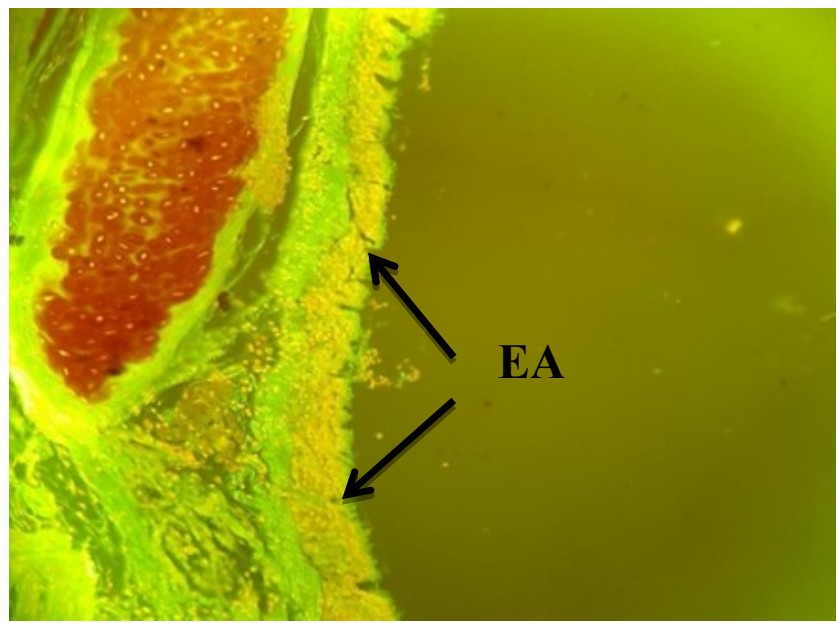

Figure 14: Microphtograph by fluorescent microscope analysis of bronchi in Duck (in oil field) showing the early apoptosis (EA) was occurred in the epithelium, (AO/EB stain, 400X).

\section{Conclusions}

There was not any precipitation of carbon in the mucosal layer of trachea in Al-dejeli, Al-ahdab oil field and brick factories areas. In Aldejeli area (healthy area), there wasn't any accumulation of carbon particles in the epithelium that lined the bronchi. In Al-ahdab oil field and brick factories areas, showed that the carbon deposit in mucosal layer of bronchi but in Al-ahdab oil field area the amount of precipitated carbon was less than the amount deposited in the brick area. The late apoptosis was occurring in all epithelial cells of bronchi in the brick 
factories area, while, early apoptosis appeared in the bronchi epithelium in oil fields area.

\section{Reference}

1. Al- badri AM, Al-Salman AA. Histological and Immunohistochemistry Studies of Trachea Calcification in the Laying Hens (Gallus gallusdomesticus). Int $J$ Sci Eng Res. 2016;4(7):11-16.

2. Dyce KM, Sac WO, Wensing CJG. Textbook of Veterinary Anatomy. 4th Edition. Saunders Elsevier. 2010; pp:799-804.

3. Öcal K, Erden H. Solunum sistemi. Evcil Kuşlarnn Anatomisi. Medisan Publisher, Ankara. 2002;pp:91-102.

4. King AS, Mclelland J. Respiratory System of Birds their Structure and Function, $2^{\text {ed }}$, Bailiere Tindall, England. 1984;pp: 110-144.

5. Getty R. Aves respiratory system. In: Anatomy of domestic animals. W.S. saunders co. Philadelphia. 1975;pp:1884-1917

6. Bacha WJ. Color Atlas of Veterinary Histology Philadelphia, Lippincot Williams \& Wilkins. 1990;pp:187.

7. Lbe CS, Onyeanusi BI, Salami SO, Umosen AD, Maidawa SM. Studies of the Major Respiratory Pathways of the west African Guinea Fowl. Int J Poul Sci. 2008;10:997-1000.

8. Demirkan AÇ, Haziroglu RM, Kurtul I. Air sacs (Sacci pneumatici) in mallard ducks (Anas Platyrhynchos). Ankara Univ Vet Fak Derg. 2006;53:75-78

9. Alumeri SKW, Al-Mamoori NAM. Grossly and Microscopic Study of the Primary Bronchi and Lungs of Wood Pigeon (Columba palumbus). Kufa J Vet Med Sci. 2013;4(2):72-79.

10. Bacha WJ, Bacha LM. Color Atlas of Veterinary Histology 2nd (ed.): Lippincott Williams \& Wilkins. 2000;pp:175-190.

11. El-Bab MRF. Textbook Fundamentals of the Histology of Birds. 3ed edition. Assiut University. 2004;pp:36-56.

12. Oxtoby DW, Gillis PH, Butler LH. Principles of modern chemistry, Cengage Learning. 2015.

13. Schaap M, Gon HAC, Denier van der. On the variability of black smoke and carbonaceous aerosols in the Netherlands. Atmosph Environ. 2007;41:5908-5920.

14. Roorda-Knape M, Janssen N, Hartog J, Van vliet P, Harssema H, Brunekreef B. Air pollution from traffic in city districts near major motorways. Atmosph Environ. 1998;32:1921-1930.

15. Quincey P. A relationship between Black Smoke Index and Black Carbon concentrations. Atmosph Environ. 2007;41:7964-7968.

16. Cyrys J, Heinrich J, Hoek J, Meliefste K, Lewné M, Gehring U, Bellander $T$, Fischer $P$, van Vliet $P$, Brauer $M$, Wichmann $H$, Brunekreef B. Comparison between different traffic-related particle indicators: elemental carbon, PM2.5 mass, and absorbance. J Expo Analy Environ Epidemiol. 2003;13:134-143.

17. Naeye R. The pneumoconiosis; coal worker's pneumoconiosis. Pathol Pulmon Disease. Philadelphia: JB Lippincott. 1994; pp:369385.

18. Amoli K. Bronchopulmonary disease in Iranian housewives chronically exposed to indoor smoke. Eur Respir J Mar.1998;11(3):659-663.

19. Kim YJ, Jung CY, Shin HW, Lee BK. Biomass smoke induced bronchial anthracofibrosis: presenting features and clinical course. Respir Med. 2009;103(5):757-765.
20. Bancroft J D, Stevens A. Theory and Practice of Histology Techniques. 8th ed. Churchil Livingstone. 2013;pp:127-129.

21. Lenka Bittnerová, Alena Jiroutová, Emil Rudolf, Martina Řezáčová and Jiří Kanta. Effect of collagen I gel on apoptosis of rat hepatic stellate cells. Acta Medica (Hradec Králové). 2013;56(2):73-79.

22. Yersin AG, Eders FW, Simmons DG. Tracheal cilia response to exogenous Niacin in drinking water of turkey poults infected. North Carolina State Uni. 1991;33:674-680.

23. Baumel JJ, King AS, Breazile JE, Evans HE, Vandan Berge JC. Respiratory system. In: Hand book of Avian Anatomy Nomina Anatomica Avium 2nd (ed.): Club. Cambridge, Massachusetts. 1993;pp:257-299.

24. Brown RE, Brain JD, Wang N. The avian respiratory system: A unique model for studies of respiratory toxicosis and for monitoring air quality. Environ Health Perspect. 1997;105:188-200.

25. Aughey E, Frye FL. Comparative Veterinary Histology with Clinical Correlates. Manson publishing. USA. 2001;pp: 93 - 95.

26. Jeffery PK. Structure and function of mucus-secreting cell of cat and goose airway epithelium. Exp Eye Res. 2004;78(2):187-196.

27. Ylidiz H, Yildiz B, Ilker A. Structure of the Bursa roller pigeon (columbalivia). Morphological Company Pub. USA. 2005;pp:81.

28. Samuelson D. Textbook of veterinary histology. Respiratory system. Saunders, Elsevier. USA. 2007:pp:224-249.

29. Al- Salman AAI. Histological and Immunohistochemistry Studies of Trachea and Syrinx Calcification in the Laying Hens (Gallus gallusdomesticus). Thesis. Collage of Science, Wasit University. 2016.

30. Maina JN. Comparative Respiratory Morphology: Themes and Principles in the Design and Construction of the Gas Exchangers. Anat Rec B New Anat. 2000;261:25-44.

31. Maina JN, Africa M. Inspiratory aerodynamic valving in the avian lung: Functional morphology of the extra-pulmonary primary bronchus. J Exp Biol. 2000;203:2865-2876.

32. Nganpiep LN, Maina JN. Composite cellular defense stratagem in the avian respiratory system: functional morphology of the free (surface) macrophages and specialized pulmonary epithelia. J Anat. 2002;200:499-516.

33. Swenson MJ. Ducks physiology of domestic animals. 9th (Ed): Darya Garya Ganj., New Delhi. India. 2004;pp: 203.

34. Aspinall V, O'Reilly M. Bird respiratory system. In: Introduction to Veterinary Anatomy and Physiology. Butter Worth-Heine Mann. 2005;pp:164-168.

35. Hodges RD. The Histology of the Fowl. CA Academic Press, London. England. 1974.pp.113-149.

36. Filep Á, Fodor GH, Kun-Szabó F, Tiszlavicz L, Rázga Z, Bozsó G, Bozóki Z, Szabó G, Peták F. Exposure to urban PM1 in rats: Development of bronchial inflammation and airway hyperresponsiveness. Resp Res. 2016;17(1);47-53.

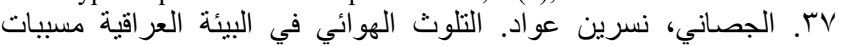

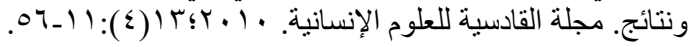

38. Atale N, Gupta S, Yadav UCS, Rani A. Cell death assessment by fluorescent and non-fluorescent cytosolic and nuclear staining techniques. J Microscopy. 2014;255(1):7-19. 